American Journal of Environmental Sciences 7 (1): 82-89, 2011

ISSN 1553-345X

(C) 2010 Science Publications

\title{
Rainfall Variation and Changing Pattern of Agricultural Cycle
}

\author{
${ }^{1}$ Md. Mahmudul Alam, ${ }^{2}$ Mohd Ekhwan bin Toriman, \\ ${ }^{1}$ Chamhuri Siwar and ${ }^{3}$ Basri Talib \\ ${ }^{1}$ Institute for Environment and Development, \\ ${ }^{2}$ School of Social, Development and Environmental Studies, \\ ${ }^{3}$ School of Economics, Faculty of Economics and Business, \\ University Kebangsaan Malaysia, \\ 43600 UKM Bangi, Selangor, Malaysia
}

\begin{abstract}
Problem statement: The decision of crop selection and the output of agricultural production are highly determined by the environmental factors, especially rainfall and water availability. In the tropical area, particularly in Malaysia, influences of these exogenous variables are so high that overall agricultural productions are now vulnerable. Crops are affected through rainfall in two different ways-high and low rainfalls. Avoiding the problem of low rainfall is nearly possible through irrigation, but over rainfall at the end of crop cycle causes destructive damages of the output. Approach: This study uses descriptive statistics to analyze the fact and uses unit root test to measure the predictability of rainfall. The raw data is taken from 8 stations from 1980 to 2007. Results: Shifting crop cycle is also not fruitful due to un-predictive changes of rainfall. All combination of crop cycle is also affected in a similar way. Government subsidy in agricultural sector is remarkably increasing, but farmers are not able to cope properly with the environmental changes, especially for the cash crops and seasonal crops production. Conclusion: Under this circumstance, in the short run, adaptation approaches should be followed in farmer level and policy level. In the long run, technological advancement will play the most crucial role to solve the problem.
\end{abstract}

Key words: Climate change, rainfall variation, agricultural cycle, irrigation water, agricultural productivity, Integrated Agricultural Development Area (IADA)

\section{INTRODUCTION}

Agriculture is primarily and heavily dependent on climate. The climatic factors- rainfall, sunshine hours, temperature, relative humidity and length of the drought period- result in cycle-to-cycle variability of crops production. The uncontrollable natures of climate factors are changing over time affecting agricultural, economic, social and environmental sustainability of a country.

Different trends show an increase in average temperature and more volatile rainfall patterns (National Research Council, 2001). Rainfall is one of the most important climatic variables because of its two sided effects - as a deficient resource, such as droughts and as a catastrophic agent, such as floods. Several studies have been carried out on rainfall at different temporal scales - from daily to annual and in different areas. It is expected to result in long-term water and other resource shortages, degrading soil condition, disease and pest outbreaks on crops and livestock and so on. It affects different crops differently. Therefore, changes in outputs and economic returns from different crops differ significantly which in turn also affects the corresponding crop growers differently. Farmers will be expecting losses, primarily, due to reductions in agricultural productivity, crop yields and loss of farm productivity.

About $60 \%$ of the world and $90 \%$ for sub-Saharan African staple food production are under direct rainfed agriculture (Savenije, 2001). However, in sub-Saharan Africa most of the crop failures are due to deficit in soil moisture (Hatibu et al., 2000) caused by dry spells. Previous studies have found that annual decreases in precipitation in eastern part (Amanatidis et al., 1993; Kutiel et al., 1996), central part (Piervitali et al., 1998)

Corresponding Author: Md. Mahmudul Alam, Institute for Environment and Development (LESTARI), University Kebangsaan Malaysia, Malaysia and Integrated Education and Research Foundation, Dhaka, Bangladesh, 
Am. J. Environ. Sci., 7 (1): 82-89, 2011

and western part (Esteban-Parra et al., 1998; De Luis et al., 2000) of Mediterranean areas. While working on the island of Sicily (Italy-Southern centre of Mediterranean Sea), found a general decreases of annual rainfall with a decreasing trend for some rain gauges around Palermo area (Aronica et al., 2002). Bonaccorso et al. (2005) analyzed the trends of annual maximum rainfall series of Mediterranean areas and found different behavior pattern based on the different time scale, particularly shorter duration series show increasing trends and longer duration series show decreasing trends.

On the other hand, averaged precipitation is expected to increase globally (Houghton et al., 2001) while the magnitude of regional precipitation changes varies among models, with the range $0-50 \%$ where the direction of change is strongly indicated and around $-30 \%$ to $+30 \%$ where it is not. Projection shows increase in northern high-latitude regions in winter, whereas reduces in subtropical latitudes (Giorgi and Francisco, 2000). For some areas, it shows a positive trend in the daily intensity and a tendency toward higher frequencies of extreme rainfall in the last few decades (Intergovernmental Panel on Climate Change, 1995). Among them, the main areas where significant positive trends have been observed are USA (Karl et al., 1995; Trenberth, 1998), eastern and north-eastern Australia (Suppiah and Hennessey, 1998; Plummer et al., 1999), South Africa (Mason et al., 1999; Hamdi et al., 2009), UK (Osborn et al., 2000) and northern and central Italy (Brunetti et al., 2000; 2001; Aung et al., 2009; Kafaki et al., 2009).

Fuhrer et al. (2006) reviewed on Europe that both rain-day frequency and intensity during winter increases towards the north (about $45^{\circ} \mathrm{N}$ ), while the rain-day frequency decreases to the south. This is also consistent with the increases of mean winter precipitation by $10-30 \%$ over most of central and northern Europe and decreases over the Mediterranean. In the summer, the most notable change is strong decreases in the frequency of wet days; for instance, about half in the Mediterranean, along with a $20-50 \%$ decrease of mean summer precipitation. In the tropics, models show an increase in Africa, a small increase in South America, but no change in Southeast Asia. Summer precipitation is expected to decrease in the Mediterranean-basin and in regions of Central America and north-western Europe. Most cases when there is a positive trend in rainfall intensity, an increase in total precipitation has also been observed (Groisman et al., 1999). However this relationship is not universal. Observation shows there is an increase in heavy precipitation in some areas (i.e., Italy) with a tendency toward a decrease in total precipitation (Brunetti et al., 2001).

Agriculture is the principal user of all water resources, such as, rainfall (so-called green water) and water in rivers, lakes and aquifers (so-called blue water). Irrigation is responsible for about $72 \%$ of global and $90 \%$ of developing country water withdrawals (FAO, 2003). Around $80 \%$ of the world's agricultural land is rainfed which contributes at least two-thirds of global food production. At the same time, irrigation plays an important role in supplying food. About $20 \%$ cropland of the world is irrigated, with a major fraction located in Asia, producing about $40 \%$ of the global crop yield annually (Newton, 2007). In spite of the higher risks in rainfed agriculture, especially in drought-prone areas, there is no alternative but most of the food comes from rainfed agriculture.

On the other hand, rainfall plays a destructive role for agriculture. Heavy rainfall at the end of the crop cycle causes damages of crops and financial losses to the farmers. Excessive rainfall also causes flood that makes huge damages of crops and farmers' effort useless.

In respect to Malaysia, the simulated results indicate both increases and decreases in rainfall that causes serious concern for agricultural production. The changes in rainfall may fluctuate from about $-30 \%$ to $+30 \%$. This change will reduce crop yield and many areas will be prone to drought hence becoming unsuitable for the cultivation of some crops such as rubber, oil palm and cocoa. Rainfall variability increases the level of environmental stress that affects the capability of the system to maintain productivity (Tisdell, 1996). The actual farm yields of rice in Malaysia vary from 3-5 tons per hectare, where potential yield is 7.2 tons.

Total yearly rainfall in Malaysia is increasing but its monthly variation is too high. Higher rainfall in a certain time affects the agricultural outcome more destructively. Though the effect of lower rainfall is reasonably possible to check through proper irrigation system, the opposite phenomenon of over rainfall in any particular time, especially at the end of the crop cycle or at the maturating period of crop, causes serious damages to crops, which is absolutely uncontrollable. This article analyzes the pattern of rainfall variation that causes changes in the crop cycle and its effectiveness with policies option for better coping abilities along with rainfall variation.

\section{MATERIALS AND METHODS}

This study uses the raw data set from Integrated Agricultural Development Area (IADA), West Selangor, Malaysia. IADA in West Selangor consists of 
eight areas- Sawah Sempadan, Sg. Burong, Sekinchan, Sg. Leman, Pasir Panjang, Sg. Nipah, Panchang Bedena, Bagan Terap- where it measures the value of the variable for each area separately.

This study uses descriptive statistics to analyze the fact and uses unit root test to measure the statistical predictability of rainfall. The raw data is taken from eight stations from 1980 to 2007. For the unit root test, this study uses the average value of all eight areas.

\section{RESULTS}

\section{Patterns of the Rainfall Variation:}

Variation over time: The average monthly rainfall data from 1980-2007 in North West Selangor shows the data is unit root; meaning, non-stationary except for the series of August and September (Table 1). In August and September the rainfall pattern shows a random walk model; meaning, unpredictable nature of data. Yet, Fig. 1 provides a very clear idea about the yearly distribution of rainfall for a particular month. The variation of rainfall is very high overall; hence, making it difficult to predict the rainfall nature for any particular month. Figure 2 shows the standard deviation of the monthly rainfall data across the areas for the year 1980-2008. Based on the high variation of rainfall, it is tough for farmers to make proper and on time decision.

Variation over place: Though all the areas under IADA are geographically very close (Fig. 3), the variation of rainfall is very high. At a particular time the rainfall does not correlate, despite being very short distanced areas. The nature of rainfall distribution is random across the areas and periods (particular month in different year). As a result the pattern of rainfall can be regarded as not understandable and uncertain.

\section{Patterns of the Agricultural Cycle Changes:}

Variation in irrigation cycle: Under the IADA, North West Selangor, total available land for paddy production is 18,934 ha. The irrigation water is supplied from the river of Tengi and Bernam. Subsequently, 560 mcm water is needed for irrigation; Yet, only $539 \mathrm{mcm}$ was available for irrigation in 2006 as it depends on the availability of water in the river. Presently, the river could only supply a maximum of $85 \%$ from the required amount. There are 59,000 ha of mangrove forest that is also depended on these rivers. Hence, any disruption to the ecosystem of the mangrove forest, where mangrove ecosystems are strongly correlated with water, will result possible serious water shortage in the future.

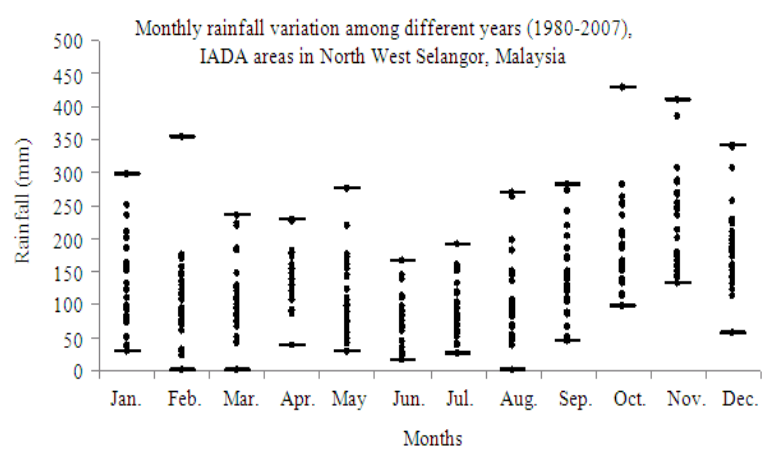

Fig. 1: Monthly Rainfall Variation under IADA areas among Different Years from 1980-2007

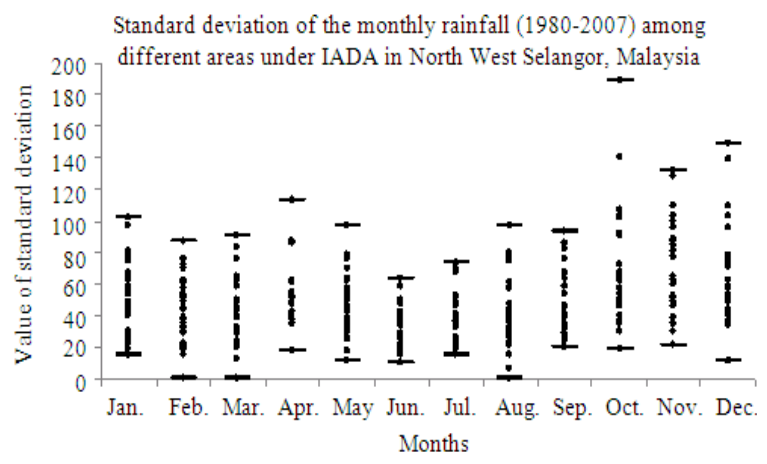

Fig. 2: Standard Deviation of the Monthly Rainfall Data across the Areas under IADA in North West Selangor, Malaysia

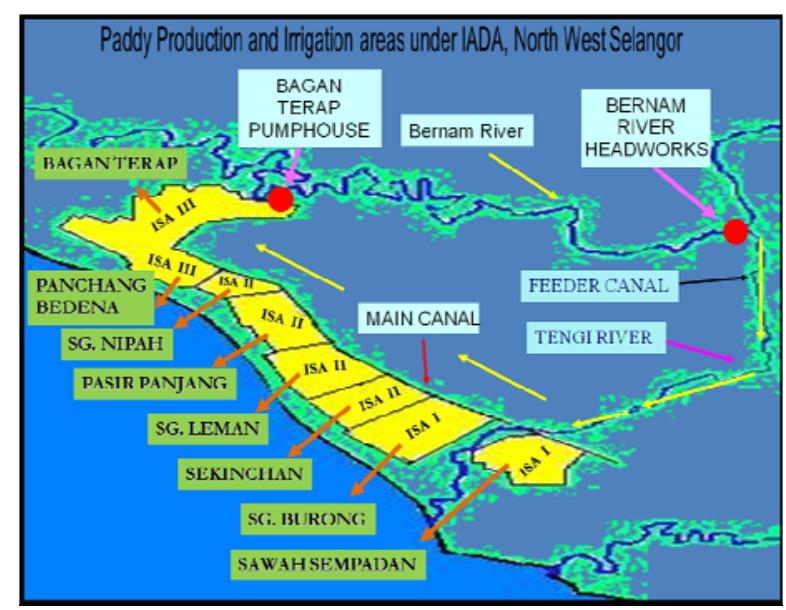

Fig. 3: Geographical Distance among the Paddy Production and Irrigation Areas under IADA in North-West Selangor, Malaysia 
Am. J. Environ. Sci., 7 (1): 82-89, 2011

Table 1: Unit root test (ADF) of monthly rainfall data in North West Selangor, Malaysia

\begin{tabular}{llllllll}
\hline & Adjusted & & & t- Critical \\
Data series & observations & ADF t-value & DW stat & $\begin{array}{l}\text { t- Critical } \\
\text { value (5\%) }\end{array}$ & $\begin{array}{l}\text { t- Critical } \\
\text { value (10\%) }\end{array}$ & Decision \\
\hline Jan. & 27 & -4.224 & 1.972 & -3.699 & -2.976 & -2.627 & No Unit Root \\
Feb. & 25 & -4.044 & 2.011 & -3.724 & -2.986 & -2.633 & No Unit Root \\
Mar. & 27 & -4.764 & 1.927 & -3.699 & -2.976 & -2.627 & No Unit Root \\
Apr. & 27 & -4.408 & 1.952 & -3.699 & -2.976 & -2.627 & No Unit Root \\
May & 27 & -5.013 & 2.109 & -3.699 & -2.976 & -2.627 & No Unit Root \\
Jun & 26 & -4.604 & 1.916 & -3.711 & -2.981 & -2.629 & No Unit Root \\
Jul. & 26 & -3.804 & 1.867 & -3.711 & -2.981 & -2.629 & No Unit Root \\
Aug. & 26 & $-1.983 *$ & 1.830 & -3.711 & -2.981 & -2.629 & Unit Root \\
Sep. & 25 & $-1.765 *$ & 1.666 & -3.724 & -2.986 & -2.633 & Unit Root \\
Oct. & 26 & -5.849 & 1.887 & -3.711 & -2.981 & -2.629 & No Unit Root \\
Nov. & 25 & -5.551 & 1.731 & -3.724 & -2.986 & -2.633 & No Unit Root \\
Dec. & 26 & -4.991 & 1.737 & -3.711 & -2.981 & -2.629 & No Unit Root \\
\hline
\end{tabular}

*,^ and $\sim$ are significant at the $1 \%, 5 \%$ and $10 \%$-level, respectively

Table 2: Irrigation schedule for paddy production in North West Selangor, Malaysia

\begin{tabular}{|c|c|c|c|c|c|c|c|c|c|c|c|c|c|}
\hline Areas & Size of the Area (Ha) & Jan. & Feb. & Mar. & Apr. & May & Jun & Jul. & Aug. & Sep. & Oct. & Nov. & Dec. \\
\hline Sawah Sempadan & 2,395 & $\mathrm{I}$ & $\mathrm{I}$ & & I & $\mathrm{I}$ & & & I & I & $\mathrm{I}$ & $\mathrm{I}$ & \\
\hline Sg. Burong & 3,616 & I & I & & I & I & & & I & I & I & I & \\
\hline Sekinchan & 1,857 & & & I & & & I & & & & I & & I \\
\hline Sg. Leman & 2,133 & & & I & & & I & & & & I & & I \\
\hline Pasir Panjang & 1,616 & & & I & & & I & & & & I & & I \\
\hline Sg. Nipah & 2,018 & & & I & & & I & & & & I & & I \\
\hline Panchang Bedena & 3,350 & I & & & I & & & I & & & & I & \\
\hline Bagan Terap & 2,870 & I & & & I & & & I & & & & I & \\
\hline
\end{tabular}

*: I = Irrigation

Table 3: Monthly average rainfall from 2000- 2007 and Crop production cycle for paddy in North West Selangor, Malaysia

\begin{tabular}{|c|c|c|c|c|c|c|c|c|c|c|c|c|c|}
\hline & Month & Jan & Feb & Mar & Apr & May & Jun & Jul & Aug & Sep & Oct & Nov & Dec \\
\hline \multirow[t]{3}{*}{ Sawah Sempadan } & Rainfall & 194.2 & 122.7 & 79.6 & 150.4 & 80.4 & 121.3 & 102.8 & 69.4 & 163.6 & 189.6 & 258.6 & 232.7 \\
\hline & Irrigation & I & I & & I & I & & & I & I & $\mathrm{I}$ & I & \\
\hline & Crop cycle & $\mathrm{P}$ & & & $\mathrm{H}$ & & & $\mathrm{P}$ & & & $\mathrm{H}$ & & \\
\hline \multirow[t]{3}{*}{ Sg. Burong } & Rainfall & 161.4 & 109 & 103.6 & 144.6 & 110.3 & 99.1 & 90.7 & 95.6 & 137.3 & 299.9 & 247.9 & 182 \\
\hline & Irrigation & I & I & & I & I & & & I & I & I & I & \\
\hline & Crop cycle & & $\mathrm{P}$ & & & $\mathrm{H}$ & & & $\mathrm{P}$ & & & $\mathrm{H}$ & \\
\hline \multirow[t]{3}{*}{ Sekinchan } & Rainfall & 140.4 & 108.8 & 78.4 & 105.2 & 94.1 & 90.8 & 110.9 & 105.7 & 153 & 271.5 & 212.4 & 159.3 \\
\hline & Irrigation & & & I & & & I & & & & I & & I \\
\hline & Crop cycle & & $\mathrm{P}$ & & & $\mathrm{H}$ & & & $\mathrm{P}$ & & & $\mathrm{H}$ & \\
\hline \multirow[t]{3}{*}{ Sg. Leman } & Rainfall & 144.1 & 123.6 & 112.4 & 113 & 76.9 & 95.7 & 97.9 & 94.6 & 154.4 & 256.6 & 228.2 & 121.8 \\
\hline & Irrigation & & & I & & & I & & & & I & & I \\
\hline & Crop cycle & & & $\mathrm{P}$ & & & $\mathrm{H}$ & & & $\mathrm{P}$ & & & $\mathrm{H}$ \\
\hline \multirow[t]{3}{*}{ Pasir Panjang } & Rainfall & 149 & 115.2 & 101.7 & 108.4 & 82.7 & 97.1 & 74.8 & 82.3 & 126.3 & 231.4 & 236.3 & 157.6 \\
\hline & Irrigation & & & I & & & I & & & & I & & I \\
\hline & Crop cycle & & & $\mathrm{P}$ & & & $\mathrm{H}$ & & & $\mathrm{P}$ & & & $\mathrm{H}$ \\
\hline \multirow[t]{3}{*}{ Sg. Nipah } & Rainfall & 146.1 & 115.3 & 108.4 & 100.7 & 65.9 & 88.4 & 102.7 & 78.8 & 179.1 & 180.6 & 223.7 & 159.9 \\
\hline & Irrigation & & & I & & & I & & & & I & & I \\
\hline & Crop cycle & & & $\mathrm{P}$ & & & $\mathrm{H}$ & & & $\mathrm{P}$ & & & $\mathrm{H}$ \\
\hline \multirow[t]{3}{*}{ Panchang Bedena } & Rainfall & 86.4 & 134.9 & 93.5 & 127.9 & 78.7 & 78.1 & 57.4 & 55.2 & 152.3 & 174 & 223.6 & 151.5 \\
\hline & Irrigation & I & & & I & & & I & & & & & \\
\hline & Crop cycle & $\mathrm{H}$ & & & $\mathrm{P}$ & & & $\mathrm{H}$ & & & $\mathrm{P}$ & & \\
\hline \multirow[t]{3}{*}{ Bagan Terap } & Rainfall & 103.6 & 127 & 84.4 & 133.9 & 73.9 & 99.9 & 92 & 75.3 & 170.2 & 179.4 & 164.1 & 100.9 \\
\hline & Irrigation & I & & & I & & & I & & & & I & \\
\hline & Crop cycle & $\mathrm{H}$ & & & $\mathrm{P}$ & & & $\mathrm{H}$ & & & $\mathrm{P}$ & & \\
\hline
\end{tabular}

* Here, $\mathrm{P}$ = Planting, $\mathrm{H}$ = Harvesting and I = Irrigation

Table 4: Future rainfall and temperature change projections in peninsular Malaysia by 2050

\begin{tabular}{ll} 
Table 4: Future rainfall and temperature change projections in peninsular Malaysia by 2050 \\
\hline
\end{tabular}

*: Difference (change) = Average 2025-2034 and 2041-2050 minus Average 1984-1993 Source: Kavvas et al., 2006 
For any particular month, water is not sufficient for supply to all areas due to the unpredictable rainfall pattern for different areas. Under this circumstances, to maintain the ecological balance and provide maximum supply of water, the timing of irrigation is scheduled separately (Table 2) for different areas. Total area is segregated in three irrigation sectors. Sawah Sempadan and Sg. Burong are under irrigation area-I. Sekinchan, Sg. Leman, Pasir Panjang, Sg. Nipah are under irrigation area-II. Panchang Bedena and Bagan Terap are under irrigation area-III.

Variation in crop cycle: Based on rainfall distribution and irrigation capacity, the production cycle of paddy is also scheduled differently for different areas (Table 3). Planting time for first season is distributed as Sawah Sempadan in January, Sg. Burong and Sekinchan in February, Sg. Leman, Pasir Panjang and Sg. Nipah in March, Panchang Bedena and Bagan Terap in April. Planting time for the second season is distributed as Sawah Sempadan in July, Sg. Burong and Sekinchan in August, Sg. Leman, Pasir Panjang and Sg. Nipah in September, Panchang Bedena and Bagan Terap in October.

\section{DISCUSSION}

As the pattern of rainfall changes over time and over locality, maintaining the current schedule of paddy production cycle (Table 3) is very challenging and ineffective. In the current schedule, there are a total sixteen harvesting sessions for two seasons consisting of eight areas under the IADA area in North West Selangor. Normally, rainfall over $25 \mathrm{~mm}$ per month is considered as heavy rainfall; whereas, among all harvesting sessions, the minimum rainfall is $57.4 \mathrm{~mm}$. In the current practices, monthly rainfall is over 100 $\mathrm{mm}$ for nine harvesting sessions and over $50 \mathrm{~mm}$ for six harvesting sessions (Table 3). Moreover, changing the timing of the crop cycle is also not effective because of the similarity in the pattern of rainfall.

There are several limitations in irrigation supply. When the full demand of agricultural water cannot be meet, it poses a threat to the ecology of this area due to the dependency of mangrove of water. Apart from that, the schedule of irrigation could not match a few areas based on the agricultural cycle. For example, Sekinchan needs irrigation at planting and harvesting time but due to the link with irrigation area II, it does not get water supply on time (Table 3). On the other hand, few areas get water supply when not necessary, such as, Sawah Sempadan gets water supply after its harvesting month for both seasons. Remarkably, though October is the highest rainfall period, six areas out of eight get irrigation which in turn causes overflow of water. Some areas get water supply only once in a crop cycle, e.g. Sekinchan, some areas get twice, e.g. Sg. Leman, Pasir Panjang, Sg. Nipah, Panchang Bedena and Bagan Terap, some area gets trice, e.g., Sawah Sempadan, Sg. Burong (first season), while some area get four times, e.g. Sg. Burong (second season).

As the rainfall pattern is uncertain, deciding for a proper irrigation schedule is becomes very difficult. As rainfall can occur anytime in the area, heavy rainfall after irrigation may harm the crop. Under this situation, the projection (Table 4) of rainfall shows very alarming situations in future. The projection also shows that by 2050 the maximum monthly precipitation will increases up to $51 \%$ over Pahang, Kelantan and Terengganu, while minimum precipitation decrease between 32-61\% for all over Peninsular Malaysia. Consequently, annual rainfall will increase up to $10 \%$ in Kelantan, Terengganu, Pahang and North West Coast and decrease up to 5\% in Selangor and Johor (Kavvas et al., 2006). As current situation of rainfall and temperature is unsuitable for agriculture, any variation of these factors will cause the total agricultural system in Malaysia to be vulnerable.

Currently there is no possible remedy for this complex and interrelated system. Shifting the crop cycle or the irrigation cycle is not fruitful. The most crucial challenge happens when the situation becomes worse because of the nature of increasing tendency, uncertainty and more volatile pattern of rainfall in near future.

Policy Recommendations: As climate change is a continuous and long term process, its effects and solutions are similarly time and effort consuming process. Molden (2007) said that there is a large yield gap in rainfed agriculture, especially in Asia and Africa, where most of the world's poor communities live. Hence, agricultural policies and investments need to be more strategic in these areas. The need to unlock the potential of rainfed agriculture to raise productivity, increase equitable access to water and conserve the natural productivity of the water resource base is crucial in these areas. Smith (2000) mentioned that a more efficient use of water in both rainfed and irrigated agriculture is essential to meet future food demands and growing competition for water. Such measures would include rainfall conservation, reduction of irrigation water losses and adoption of cultural practices. 
Existing literature mostly focuses on solving the problem of low rainfall, but not on the problem of excessive rainfall on agriculture in any particular period. It is widely accepted that strict mitigation efforts will not be sufficient to avoid significant impacts of climate change (IPCC, 2007). It is therefore important to balance between measures against the causes of climate change and measures to cope with its adverse effects (Stern, 2007; Pielke et al., 2007).

In the current world, as rainfall is exogenous and an uncontrollable factor, only adaptation with the changing nature of rainfall is the way to cope with the problem. Agricultural adaptation options can be grouped as technological developments, government programs, farm production practices and farm financial management (Smit and Skinner, 2002).

Technological adaptation is most important in dealing with the problem in the long run. To remedy the problem, improvement of technology needs to reach a certain level to control the rainfall. Based on the high uncertainty of such technological advancement in short period, adaptation related technology is more important for short term solution such as, develop resource management based technique: protect crops from excessive rainfall, solve water login problems etc., crop development: verities of crops, rainfall tolerant plants etc., crop cycle change: shift the timing of crop cycle, reduce the timing of crop cycle etc.

Government bodies need to carefully define its subsidy supports and incentive programs to influence farm-level production practices and financial management. Furthermore, it needs to define and ensure the compensation and insurance facility for the affected groups - individual farmer or farm. And it also needs to develop programs to control the influences of the usage of all types of fresh water resources and its reservation. In the planning processes it needs to account that stakeholders may not be sufficiently inform about its need and possible strategies (Eisenack and Kropp, 2006; Eisenack et al., 2007), farm level faces uncertain future and developments may hinder the process and implementation of adaptations policy (Behringer et al., 2000; Few et al., 2007) and it will deal with different conflicting interest groups.

The production practices of farm and individual farmers need to be kept up to date with the changes in climate factors. They should be informed about crop rotation, crop portfolio and crop substitutions. They should also take all precautions and be aware about the uncertainty of low rainfall and heavy rainfall. They must be careful in arranging proper water management, both in terms of irrigation facilities and quick water logout facilities. Apart from that, they also need to understand the importance of proper timing and react quickly at the sight of upcoming rainfall events. The financial management of farms and farmers too need to be secure for a minimum of two seasons so that if crop is damaged in one season, they will be prepared and have the seeds for next season; their ability to bear the cost of another crop production will guarantee their survival financially up to the collection of the new crops. For that reason, they should take the initiative for crop sharing, forward rating, hedging and insurance.

Mitigation or adaptation of climate change is an issue that concerns all sectors and levels of political, administrative, economic and everyday life. To better cope with the situation, cooperation is necessary across countries, sectors and administrative levels. Relevant parties need to be aware of the benefits of a cooperation to gain long-term benefits instead of focusing only on short-term and individual interest.

\section{CONCLUSION}

The impacts of rainfall on agricultural sustainability vary from economic condition of countries, regions and over a period of time. The crops in Malaysia are heavily influenced by rainfall variation as rainfall variation among the months and locality fluctuate too high to be conducive for paddy production. The agriculture sector could be affected either by low rainfall or excessive rainfall for any particular time within the crop cycle and any possible combination of timing for crop cycle. Hence, the shifting of crop cycle will not be fruitful. In such cases, crop damages are a regular phenomenon in recent years.

In Malaysia the projection indicates both increases and decreases in rainfall, which may fluctuate from about -30 to $+30 \%$. Therefore, adaptation is very essential for the long run of agricultural and relevant human livelihood sustainability. Adaptation approaches should be followed in farm or individual farmer level and policy level. Technological advancement will play the most crucial role in solving the problem in the long run. Technology needs to develop to solve the problem such as, to some extent control the pattern of rainfall, or to improve shielding resources such as, protecting crops from excessive rainfall, solve water login problems, or to develop defensive approach such as, verities of crops development, rainfall tolerant plants, or to find alternative approach such as, changing crop cycle, reducing the timing of crop cycle. Government bodies too need to take preferable subsidy policy and ensure financial sustainability for the farmers and farms. Overall, co-operation among different groups, stakeholders and agencies is very important to better cope with the changing nature of climate factors. 


\section{REFERENCES}

Amanatidis, G.T., A.G. Paliatsos, C.C. Repapis and J.G. Bartzis, 1993. Decreasing precipitation trend in the Marathon area, Greece. Int. J. Climatol., 13: 191-201. DOI: 10.1002/joc.3370130205

Aronica, G., M. Cannarozzo and L. Noto, 2002. Investigating the changes in extreme rainfall series recorded in an urbanised area. Water Sci. Technol., 45: 49-54. PMID: 11888183

Aung, T., A. Singh and U. Prasad, 2009. Sea level threat in tuvalu. Am. J. Applied Sci., 6: 1169-1174. DOI: 10.3844/ajassp.2009.1169.1174

Behringer, J., R. Buerki and J. Fuhrer, 2000. Participatory integrated assessment of adaptation to climate change in Alpine tourism and mountain agriculture. Integrated Assess., 1: 331-338. DOI: 10.1023/A:1018940901744

Bonaccorso, B., A. Cancelliere and G. Rossi, 2005. Detecting trends of extreme rainfall series in Sicily. Advan. Geosci., 2: 7-11. DOI: 10.5194/ADGEO-27-2005

Brunetti, M., L. Buffoni, M. Maugeri and T. Nanni, 2000. Precipitation intensity trends in Northern Italy. Int. J. Climatol., 20: 1017-1031. DOI: $\quad 10.1002 / 1097-0088(200007) 20: 9<1017:: A I D-$ JOC515>3.0.CO;2-S

Brunetti, M., M. Colacino, M. Maugeri and T. Nanni, 2001. Trends in the daily intensity of precipitation in Italy from 1951-1996. Int. J. Climatol., 21: 299-316. DOI: $10.1002 /$ joc.613

National Research Council, 2001. Climate Change Science: An analysis of Some Key Questions. 1st Edn., Committee on the Science of Climate Change, National Academy Press, Washington D.C., ISBN-10: 0309075742, pp: 29.

De Luis, M., J. Raventos, J.C. Gonzalez-Hidalgo, J.R. Sanchez and J. Cortina, 2000. Spatial analysis of rainfall trends in the region of Valencia (East Spain). Int. J. Climatol., 20: 1451-1469. DOI: 10.1002/10970088(200010)20:12<1451::AIDJOC547>3.0.CO;2-0

Eisenack, K. and J. Kropp, 2006. Regional stakeholder perceptions of climate change: baltic case study screening. Potsdam Institute for Climate Impact Research Germany.

Eisenack, K., V. Tekken and J.P. Kropp, 2007. Stakeholder perceptions of climate change in the Baltic sea region. Coastline Rep., 8: 245-255.

Esteban-Parra, M.J., F.S. Rodrigo and Y. Castro-Diez, 1998. Spatial and temporal patterns of precipitation in Spain for the period 1880-1992. Int. J. Climatol., 18: $1557-1574 . \quad$ DOI: $10.1002 /($ SICI)10970088(19981130)18:14<1557::AID-

JOC328>3.0.CO;2-J
Few, R., K. Brown and E.L. Tompkins, 2007. Climate change and coastal management decisions: Insights from Christchurch Bay. Coastal Manage., 35: 255-270. DOI: 10.1080/08920750601042328

FAO, 2003. Agriculture, food and water. FAO, Rome.

Fuhrer, J., M. Beniston, A. Fischlin, C. Frei, S. Goyette et al., 2006. Climate risks and their impact on agriculture and forests in Switzerland. Climatic Change, 79: 79-102. DOI: $10.1007 / \mathrm{s} 10584-006-9106-6$

Giorgi, F. and R. Francisco, 2000. Evaluating uncertainties in the prediction of regional climate change. Geophys. Res. Lett., 27: 1295-1298. DOI: 10.1029/1999GL011016

Groisman, P.Y., T.R. Karl, D.R. Easterling, R.W. Knight and P.F. Jamason et al., 1999. Changes in the probability of heavy precipitation: Important indicators of climatic change. Climate Change, 42: 243-283. DOI: 10.1023/A:1005432803188

Hamdi, M.R., M. Abu-Allaban, A. Al-Shayeb, M. Jaber and N.M. Momani, 2009. Climate change in jordan: A comprehensive examination approach. Am. J. Environ. Sci., 5: 58-68. DOI: 10.3844/ajessp.2009.58.68

Hatibu, N. and H.F. Mahoo and J.W. Gowing, 2000. Rainwater harvesting for natural resources management: A planning guide for Tanzania. 1st Edn., RELMA, Sweden, 996689652X, pp: 144.

Houghton, J.T., Y. Ding, D.J. Griggs, M. Noguer and P.J. van der Linden et al., 2001. Climate Change 2001: The Scientific Basis: Contribution of Working Group I to the Third Assessment Report of the Intergovernmental Panel on Climate Change. 1st Edn., Cambridge University Press, Cambridge, ISBN-10: 0521014956, pp: 892.

Intergovernmental Panel on Climate Change, 1995. Climate change 1995: IPCC second assessment : A report of the Intergovernmental Panel on Climate Change. 1st Edn., Intergovernmental Panel on climate Change, Pennsylvania State, pp: 64.

IPCC, 2007. Climate Change 2007: The Physical Science Basis. 1st Edn., Intergovernmental Panel on Climate Change, Cambridge, ISBN-10: 0521705967, pp: 1008.

Kafaki, S.B., A. Mataji and S.A. Hashemi, 2009. Monitoring growing season length of deciduous broad leaf forest derived from satellite data in Iran. Am. J. Environ. Sci., 5: 647-652. DOI: 10.3844/ajessp.2009.647.652

Karl, T.R., R.W. Knight and N. Plummer, 1995. Trends in high-frequency climate variability in the twentieth century. Nature, 377: 217-220. DOI: $10.1038 / 377217 \mathrm{a} 0$ 
Am. J. Environ. Sci., 7 (1): 82-89, 2011

Kutiel, H., P. Maheras and S. Guika, 1996. Circulation and extreme rainfall conditions in the eastern Mediterranean during the last century. Int. J. Climatol., 16: 73-92. DOI: 10.1002/(SICI)10970088(199601)16:1<73::AID-JOC997>3.0.CO;2-G

Mason, S.J., P.R. Waylen, G.M. Mimmack, B. Rajaratnam and J.M. Harrison, 1999. Changes in extreme rainfall events in South Africa. Climate Change, 41: 249-257. DOI: 10.1023/A:1005450924499

Molden, D., 2007. Water for Food, Water for Life: A Comprehensive Assessment of Water Management in Agriculture. 1st Edn., Earthscan, UK., ISBN-10: 1844073963, pp: 645.

Kavvas, M. L., Z.Q. Chen and N. Ohara, 2006. study of the impact of climate change on the hydrologic regime and water resources of peninsular Malaysia. California Hydrologic Research Laboratory

Newton, P.C.D., 2007. Agroecosystems in a Changing Climate. 1st Edn., CRC/Taylor and Francis, New York, ISBN-10: 0849320887, pp: 364.

Osborn, T.J., M. Hulme, P.D. Jones and T.A. Basnett, 2000. Observed trends in the daily intensity of United Kingdom precipitation. Int. J. Climatol., 20: 347-364. DOI: 10.1002/(SICI)10970088(20000330)20:4<347::AIDJOC475>3.0.CO;2-C

Pielke, R., G. Prins, S. Rayner and D. Sarewitz, 2007. Climate change 2007: Lifting the taboo on adaptation. Nature, 445: 597-598. DOI: 10.1038/445597a

Piervitali, E., M. Colacino and M. Conte, 1998. Rainfall over the centralwestern mediterranean basin in the period 1951-1995. Part I: precipitation trends. Nuovo Cimento della Societa Italiana di Fisica CGeophys. Space Phys., 21: 331-344.
Plummer, N., M.J.. Salinger, N. Nicholls, R. Suppiah and K.J. Hennessy et al., 1999. Changes in climate extremes over the Australian region and New Zealand during the twentieth century. Climate Change, 42: 183-202. DOI: 10.1023/A:1005472418209

Savenije, H.H.G., 2001. The role of Green Water in Food Production in sub-Saharan Africa. FAO, The Netherlands.

Smit, B. and M.W. Skinner, 2002. Adaptation options in agriculture to climate change: A typology. Mitigation Adapt. Strat. Global Change, 7: 85-114. DOI: 10.1023/A:1015862228270

Smith, M., 2000. The application of climatic data for planning and management of sustainable rainfed and irrigated crop production. Agri. For. Meteorol., 103: 99-108. DOI: $10.1016 / S 0168-1923(00) 00121-0$

Stern, N.H., 2007. The Economics of Climate Change: The Stern Review. 1st Edn., Cambridge University Press, Cambridge, ISBN-10: 0521700809, pp: 692.

Suppiah, R. and K.J. Hennessey, 1998. Trends in total rainfall, heavy rain events and number of dry days in Australia, 1910-1990. Int. J. Climatol., 18: 11411164. DOI: 10.1002/(SICI)10970088(199808)18:10<1141::AIDJOC286>3.0.CO;2-P

Tisdell, C., 1996. Economic indicators to assess the sustainability of conservation farming projects: An evaluation. Agri. Ecosyst. Environ., 57: 117-131. DOI: 10.1016/0167-8809(96)01017-1

Trenberth, K.E., 1998. Atmospheric moisture residence times and cycling: Implications for rainfall rates and climate change. Climate Change, 39: 667-694. DOI: 10.1023/A:1005319109110 